PF 2020 (75/1): 313-322

https://doi.org/10.32798/pf.663

\author{
MAŁGORZATA KORYTKOWSKA \\ professor emeritus \\ Instytut Slawistyki PAN, Warszawa \\ e-mail:mal_kor@wp.pl \\ ORCID 0000-0003-3887-4822
}

\title{
WOKÓŁ OPISU CECH WALENCJI CZASOWNIKÓW TYPU: POL. ŚCIEMNIEĆ, WYGŁADZIĆ SIĘ; BUŁG. ИЗРУСЯ CE, ИЗГЛАДЯ СЕ
}

\author{
TOWARDS DESCRIPTION OF THE VALENCY FEATURES OF VERBS \\ SUCH AS POLISH ŚCIEMNIEĆ, WYGŁADZIĆ SIĘ \\ AND BULGARIAN ИЗРУСЯ СЕ, ИЗГЛАДЯ СЕ
}

\begin{abstract}
The article covers a semantic and syntactic interpretation of sentence structures expressing part : whole relation with respect to an animate subject ([+anim / and + hum $]$ traits), and the subject's body parts, e.g. Włosy Piotrusia ściemniały. (with the variant Włosy Piotrusiowi ściemniały.). The author refers to theoretical grounds of predicate-argument syntax, including the fundamental model introduced by S. Karolak. Structures like this, in which predicates constituting sentence structures open one argument position, can be interpreted in two ways. What is discussed in particular is the structure of this argument, as well as of its counterparts in the Bulgarian language. In addition, the discussion covers another verb type (boleć 'to ache, to hurt'), which also opens a position for one semantically compound argument in S. Karolak's classification. In the author's view the inclusion of czuć / doznawać ('to feel') component into the semantic structure of these verbs indicates that they are two-argument predicates.
\end{abstract}

KEYWORDS: relation part: whole, predicate-argument structure, one-place predicate, argument expression, Polish-Bulgarian contrast 
SŁOWA KLUCZOWE: relacja całość : część, struktura predykatowo-argumentowa, predykat jednomiejscowy, wyrażenie argumentowe, język polski $v s$. bułgarski

1. Omawiany w artykule materiał językowy ilustruje zjawiska, nasuwające pewne problemy interpretacyjne w opisie bazującym na modelu składni semantycznej (eksplikacyjnej), w której jedną z podstawowych cech predykacji jest charakterystyka elementu pełniącego funkcję predykatu pod względem otwieranych przez niego pozycji argumentowych. Fundamentalny model opisu składni wyrażeń predykatywnych języka polskiego stworzony został przez Stanisława Karolaka (Karolak 1984). Stał się on podstawą, na której opierało się wielu późniejszych badaczy ${ }^{1}$. Przedstawione niżej interpretacje w p. 1 mieszczą się w modelu, który też czerpie z założeń składni semantycznej, ale który nieco szerzej odwołuje się do ujęcia eksplikatywnego przy interpretacji struktur zdaniowych. W p. 2 przedstawione zostało ujęcie S. Karolaka. Analizowane tu czasowniki wymagają zawarcia w strukturze zdaniowej elementów (fraz bądź komponentów wchodzących poza jądrem zdaniowym w strukturę frazy nominalnej), które odnoszą się do istoty żywej oraz części jej ciała. Poniższe zdania są przykładem struktur, które poddane zostały w tekście analizie, koncentrującej się na problemach ich opisu (modelowania):

(A) Włosy Piotrusia ściemniały. / Jego włosy ściemniały.

(B) Włosy Piotrusiowi ściemniały.

1.1. Do specyficznych cech semantycznych omawianego tu typu zdań należą obligatoryjne cechy frazy podmiotowej w strukturach (A). Jej centrum $\left(\mathrm{N}_{\text {nom }}\right)$ odnosi się do części ciała jednostki, która wskazana jest poprzez element pełniący funkcję przydawki rzeczownej (zaimka Pron $_{\text {gen }}$ w przypadku anafory). Sprowadzenie frazy podmiotowej jedynie do centrum występuje głównie w zdaniach ogólnych (z czym wiąże się zmiana aspektu), por. np.: (Pod wplywem promieni słonecznych) zwykle włosy jaśnieją.

1.2. Istotne trudności sprawia interpretacja i zapis wskazanej wyżej struktury typu (A), co wynika właśnie ze złożoności semantycznej frazy podmiotowej, głównie zaś wiąże się z problemem interpretacji szeroko pojmowanej relacji całość : część. Najbardziej naturalną parafrazą zdania (A) Włosy Piotrusia ściemniały. jest taka, która zawiera zdanie zależne, podrzędne (zanurzone / składnikowe w terminologii transformacyjnej (Polański 1995)) typu:

(A’) Włosy, które są częścią ciała Piotrusia / które ma Piotruś), ściemniały.

1 Por. obszerną bibliografię w (Korytkowska (red.), 2019). 
Oczywiście propozycja ta rodzi dyskusję dotyczącą adekwatności stosowania w parafrazach omawianych przykładów interpretacji tego szczególnego wypadku relacji całość : część, która jest trudna do zwerbalizowania, zwłaszcza w semantycznie prostych terminach. W uzusie językowym jednak zdania typu (A') przyjmowane są jako w pełni poprawne semantycznie. W szczegółowych opisach słownikowych takie znaczenia leksemów być częścią (ciała), mieć (jako jedna z odmianek leksykalnych tego czasownika) wymagają wyodrębnienia i tak się dzieje. Takie rozwiązanie zawiera np. ISJP - por. hasło część 1.: "Część jakiejś całości to coś, co powstało w wyniku jej podziału, faktycznego lub tylko wyobrażonego, służącego wskazaniu jakiegoś miejsca, ((...) części ciała)”. Dla mieć (por. hasło mieć 3) wyodrębnione są także występowania rozbudowanych fraz, por:: „Jeśli jakaś osoba lub rzecz ma jakąś cechę, np. określoną budowę, kształt, wymiary, pozycję społeczną lub stanowisko, to one ją charakteryzują", np. Dziewczynka ma czarne oczy. (por. niżej, p. 1.2.). Por. też: Ptaki maja skrzydła. / Ten noworodek nie ma dłoni. Przyjmuje się więc, że strukturę zdania podrzędnego, określającego centrum frazy podmiotowej $\mathrm{N}_{\text {nom }}$, oddaje zapis zdania z być częściq ciała (z mieć $c_{x}$ jako konwersem):

$V N_{y} N_{x}$ gdzie argument $x$ („,całość"- ma cechy [+anim] $]_{/ \mathrm{i}}[+$ hum], a argument $y$ odnosi się do części ciała $x$-a ).

Predykaty być częścią ciała / mieć ${ }_{x}$ traktowane są jako dwuargumentowe, wyrażające relację między $x$ i $y$ - można więc powiedzieć, że zdanie występujące w pozycji podrzędnej ma charakter definicyjny dla relacji 'bycia częścią ciała'.

We frazach typu włosy Piotrusia ujawnia się więc proces specyficznej kondensacji składniowej doprowadzającej do występowania frazy $N P_{y,\{x\}}$ o złożonej budowie, w ramach której dla $x^{\prime}$ nie jest otwierana pozycja syntaktyczna o randze dopełnienia:

$$
N P_{y, x^{x}} \rightarrow N_{\text {nom }(y)}\left\{N_{g e n\left(x^{\prime}\right)}\right\}
$$

Schemat zdaniowy typu (A) oddajemy więc jako:

$$
\text { (A) } V N P_{y,\{x\}} \rightarrow V N_{\text {nom }}\left\{N_{g e n}\right\}
$$

gdzie $V$ jest predykatem I rzędu, jednoargumentowym, z wyrażeniem argumentowym $y, x^{\prime}$, a oznaczenie $x^{\prime}\left\{N_{x^{\prime}}\right\}$ wskazuje na podrzędność komponentu frazy (zanurzenie w strukturze). Por. przykłady: Twarz Anny rozjaśniła się. / (Szafirowe) oczy dziewczyny ściemniały (ze zmęczenia). Czoło ciotki rozpromieniło się. / Twoje włosy nie rozjaśnią się (niczym za dotknięciem magicznej różczki) / Palce mojej prawej dłoni zdrętwiały. / Skóra chorego wygładziła się. / (Pod wpływem choroby) jego nogi spuchły. / Wąsy Antka posiwiały. / Ogon psa wyliniał. 
1.3. Struktury typu (B) można postrzegać jako wynik przekształceń (A), w których dochodzi do swoistego podniesienia zależnej $x$; ; przyjmuje ona tu pozycję dopełnieniową ${ }^{2}$ :

(B) $V N_{\text {nom (y) }} N_{\text {dat }(x)}$

Piotrusiowi ściemnialy włosy.

Jako struktura wywodliwa z (A) predykat zachowuje charakterystykę walencyjną. Taka interpretacja jest możliwa, jeśli przyjmiemy, że funkcjonalnie fraza datywna Piotrusiowi w strukturze (B) jest tożsama z pozycją $\mathrm{N}_{\text {gen }}$ w ramach frazy podmiotowej w strukturze (A). Sprecyzowanie funkcji frazy datywnej jest kolejnym bardzo trudnym problemem. Najczęstsza interpretacja funkcji nieregowanych fraz datywnych to użycia wskazujące na jednostkę, która odnosi (/ nie odnosi) jakąś korzyść w wyniku zdarzenia, wyrażanego przez predykat (por. np. hasło Dativus w (Encyklopedia 1995; Wierzbicka 1986; por. też najnowsze studium Zuzanny Topolińskiej (Topolińska 2019)). Tradycyjnie wyróżniana funkcja posesywna datiwu, najbliższa tu omawianej, określana jest jako szczątkowa w polszczyźnie, por. np. ojciec dzieciom, na imię $\boldsymbol{m} \boldsymbol{u}$ Adam - por. Polański w (Encyklopedia 1995). W proponowanym tu opisie przyjmuje się funkcję frazy datywnej jako tożsamą z funkcją $y$ w parafrazie predykacji podrzędnej.

Por. dalsze przykłady: Włosy dziecku ściemniały. / Rzęsy ci się wydłużyły. / Cała twarz mu pociemniała. / (Od tego kremu) Marysi wygładziła się skóra na kolanach. / Babci spuchły nogi. / Ojcu posiwiały skronie. / Twarz mu zbladła.

2. W klasyfikacji predykatów polskich S. Karolak (Karolak 1984) uwzględnił omawianą tu podklasę czasowników w ramach większego zbioru typów struktur predykatowo-argumentowych $\mathrm{z}$ argumentem osobowo-rzeczowym, należących do klasy $\mathrm{f}(\mathrm{x})$, a więc jednoargumentowych.

2.1. Predykat $\mathrm{w}$ strukturach predykatowo-argumentowych typu Twarz Marii pobladła. klasyfikowany jest więc jako otwierający jedną pozycję argumentową i odnosi się on „do części ciała ludzkiego, określonych też jako nieodłączalne części całości", a otwierana przez ten predykat pozycja argumentowa ma zdaniem autora charakter osobowo-rzeczowy (w zapisie z subskryptem: $x_{\text {pers-obiect }}$ ) (Karolak 1983 , s. $152^{3}$ ). Ustalenia te bazują na rozumieniu argumentu.

$\mathrm{W}$ definicji przedmiotowej termin argument jest równoznaczny ze wskazywanym przedmiotem (konkretnego fizycznego elementu rzeczywistości)". W definicji znakowej

2 To ujęcie wynika z postrzegania zbioru struktur zdaniowych z daną odmianką znaczeniową czasownika jako uporządkowanego hierarchicznie (por. szerzej w (Korytkowska (red.) 2019)). Struktury zdaniowe wywodliwe z pełnej semantycznie podstawowej struktury zdaniowej mogą się różnić jedynie cechami formalnymi lub (często) stanowią efekt procesów kondensacyjnych, charakteryzujących się w porównaniu ze strukturą podstawową brakiem wypełnienia pewnych treści.

3 Wydaje się, że właściwe jest przyjęcie cech selektywnych [+anim] ${ }_{/ \mathrm{i}}[+$ hum], por. np. Ogon psa wyliniat. / Ogon psu wyliniał. 
argumentem jest językowy korelat wyróżnionego przedmiotu (konkretnego fizycznego elementu rzeczywistości) (Karolak 1984, s. 20).

Autor określa strukturę tego argumentu jako złożoną, ale bliższej analizy istoty złożoności argumentu określanego jako $\mathrm{C}_{\text {pers-obiect }}$ nie przeprowadza (Karolak 1984, s. 152). Zgodnie z założeniami zaprezentowane zostały typy struktur predykatowo-argumentowych, różniące się stopniem zupełności w realizacji tych cech, a także struktury zróżnicowane pod względem występujących w nich dyzjunkcji (rozszczepień) argumentów oraz realizacji formalnej predykatów (Karolak 1984, s. 108). To założenie pozwala na spójny opis cech walencyjnych predykatów $\mathrm{w}$ wariantach struktur omawianej tu klasy - pozostają one jednoargumentowe zarówno w wyżej omówionym typie (A), jak i (B).

Model odpowiadający typowi (A) oddaje zapis:

$$
V\left(C_{\text {pers-obiect }}\right) \rightarrow N_{n} N_{g} V_{f},
$$

np. Twarz Marii zbladła. / Twarz chłopca zmizerniała,

Typ (B) odzwierciedla struktura:

$$
V\left(C_{\text {pers-obiect }}\right) \rightarrow N_{n} N_{d} V_{f}
$$

np. Włosy ojcu posiwiaty.

2.2. Inne typy zanalizowane $\mathrm{w}$ (Karolak 1984, s. 153) ramach tego samego zbioru struktur $V\left(C_{\text {pers-obiect }}\right)$ to:

a) Dziewczyna zbladła na twarzy.;

b) Dziewczyna była blada na twarzy.;

c) Dziewczyna miała bladą twarz. / Prokurator oczy miał przymrużone.

Funkcja predykatywna łączona jest w tych strukturach z przymiotnikami - np. blady, mizerny, siwy, itp. Struktury zdaniowe, ilustrujące realizację predykatów jednomiejscowych, zawierają kolejne typy dysjunkcji przy wyrażaniu złożonego argumentu. W typach b) i c) - (por. niżej) - omawiany model formalno-syntaktyczny spełniają wyrażenia przymiotnikowe, por. zapisy struktur:

$$
\begin{aligned}
& \text { dla typu a): } V\left(\mathrm{C}_{\text {pers-obiect }}\right) \rightarrow N_{n} V_{f n a} N_{l} \\
& \text { dla typu b): } V\left(\mathrm{C}_{\text {pers-obiect }}\right) \rightarrow N_{n} V_{f} A_{n n a} N_{l} \\
& \text { dla typu c): } V\left(\mathrm{C}_{\text {pers-obiect }}\right) \rightarrow N_{n} V_{f} A_{a} N_{a} / / N_{n} V_{f} N_{a} A_{a}
\end{aligned}
$$

Predykat w typie a) pełni czasownik, wyrażenie predykatywne $\mathrm{w}$ b) ma charakter analityczny, którego orzecznik wyraża treść predykatu (być bladym). Trudniejsza do interpretacji formalno-syntaktycznej $\mathrm{w}$ kategoriach analizy powierzchniowej jest struktura typu c). Problem stanowi, jak się wydaje, interpretacja funkcji mieć, a także frazy $A_{a} N_{a}$ w strukturze zdaniowej, a więc to, czy należy ona do wyrażenia 
predykatywnego, czy też występuje jako fraza dopełnieniowa (co do funkcji czasownika mieć, por. też (Kruk 2019)). Zgodnie z zapisem i przyjętą klasyfikacją pozycja obiect jest nadal obecna w strukturze jako część złożonego argumentu (por. dziewczyna - twarz). Rozwiązanie to jest konsekwencją przyjętych ogólnych ustaleń teoretycznych w przez autora Składni 1984, w której ten sam model semantyczno-syntaktyczny spełniany jest „przez wszystkie wyrażenia, których składnikiem jest wyrażenie predykatywne (temat)". np.: podejrz-, a więc np. podejrzewać, podejrzenie, podejrzliwość. Tak więc zasadą przyjętą przez S. Karolaka jest, że

wszystkie warianty tematów (ciągów morfemowych) reprezentujących dany predykat (...) traktuje się jako realizacje członu konstytutywnego tej samej struktury predykatowo-argumentowej, czyli wprowadza się je do jednego modelu semantycznego,

uznając je za element zbioru jednego predykatu - chociaż poszczególne jego wykładniki leksemowe mogą w strukturach powierzchniowych realizować różną liczbę pozycji argumentowych (Karolak 1984, s. 59-60). Dlatego też trzeba wziąć pod uwagę fakt, że ujęcia zarysowane wyżej w p. 1. oraz 2. osadzone są na różnych poziomach analizy.

3. Konfrontując zbiór omawianych $\mathrm{w}$ tym tekście polskich typów struktur fundowanych na czasownikach jednomiejscowych $\mathrm{z}$ ich odpowiednikami w języku bułgarskim można odnaleźć kilka różnic.

3.1. Odpowiednikiem polskich struktur zdaniowych typu

(A) Włosy Piotrusia ściemniały. (/ Jego włosy ściemniały.) i (B) Włosy Piotrusiowi ściemniały.

jest jedynie bułgarski typ:

(A') Косата на Петър потъмня. / Косата му потъмня.

W obu wypadkach w zdaniu występuje fraza podmiotowa zawierająca przydawkę rzeczowną, której postać stanowi odzwierciedlenie historycznych procesów zaniku fleksji imiennej, tu - genetiwu, który przejściowo został zastąpiony przez dativus, a następnie wyparty przez frazy $\boldsymbol{H} a^{\wedge} N$, z zachowaniem resztek fleksji w ramach krótkich form zaimków osobowych. Tak więc typ (A'), zawierający formę zaimkową lub frazę $\mathrm{Ha}^{\wedge} \mathrm{N}$, tylko błędnie można uznać za tożsamy z polskimi strukturami typu (B) - reprezentuje on polski typ (A). Por. przykłady:

... и лицето му някак потъмня. / Веждите му бяха изрусели (и не се забелязваха). / Брадата на Емин ага побеля (в тази страшна нощ). / От тези грижи главата на Юлия побеля. / Раната й заздравя.

3.2. Spośród innych realizacji tego typu predykatów, charakteryzujących się odmiennymi cechami dysjunkcji, także nie wszystkie są dopuszczalne w bułgarskim. 
a) Dziewczyna zbladła na twarzy. / Ojciec posiwiał na skroniach. - tylko bułg. Лицето й стана бледо. / Бащза ми побеля. - a więc tu tylko typ (A').

b) Dziewczyna była blada na twarzy. - bułgarski również w tym wypadku realizuje struktury zdaniowe typu (A'): Лицето й беше бледо. / Слепоочието му (/ на бамза ми) беше сиво.

c) Dziewczyna miała bladą twarz. / Ojciec miał siwe włosy. Odpowiednikami są tu z reguły zdania typu (A’) z orzeczeniem imiennym: Лицето на Ваня беше бледо. Слепоочието му беше сиво. Tylko dla określenia cechy stałej może wystąpić typ c), nр. Той има руса коса / светли очи., ale tyр Лицето й е бледо, jest powszechniejszy.

Tak więc bułgarski, w przeciwieństwie do polskiego, preferuje w analizowanym tu materiale struktury zdaniowe lokujące w pozycji podmiotowej frazy typu лицето му, косата на Иван, z centrum frazy odnoszącym się do części ciała. Zakres struktur, których elementy można uznać za rozszczepione (dysjunktywne), jest bardzo ograniczony.

4. W klasie struktur predykatowo-argumentowych $\mathrm{z}$ argumentem osobowo-rzeczowym przy predykatach jednomiejscowych uwzględniona jest także podklasa czasowników o innej semantyce - typu boleć ${ }_{1}^{4}$, rwać, także szumieć, huczeć, por. Boli mnie głowa. I Zabolało mnie w sercu. Kowalskiego rwała ręka. itp. (Karolak 1984, s. 154) ${ }^{5}$. Por. np. zapis struktury zdania Boli mnie głowa. / Annę rozbolał ząb.:

$$
V\left(\mathrm{C}_{\text {pers-obiect }}\right) \rightarrow N_{a} V_{f} N_{n}
$$

W tym wypadku interpretacja wydaje się nie uwzględniać specyfiki semantycznej czasowników percepcji, otwierających pozycję dla frazy odnoszącej się do jednostki doznającej wrażeń fizycznych. Czasowniki tej podklasy najczęściej należą (zgodnie z klasyfikacją S. Karolaka) do reprezentujących predykaty I rzędu, ale $\mathrm{w}$ ich strukturze semantycznej odzwierciedlonej $\mathrm{w}$ parafrazie pojawia się predykat doznaniowy typu czuć, doznawać, por. np. Annę boli ręka. - Anna doznaje bardzo nieprzyjemnego wrażenia $w$ ręce. Podobne interpretacje zawierają słowniki (poza predykatem doznaniowym często jednak zawierają one parafrazy zawierające znominalizowany predykat - ból, czego należało by unikać), por.:

boleć 1 . Jeśli boli nas jakaś część ciała, to odczuwamy w niej ból. (ISJP).

(1. Ból to 1.1. bardzo nieprzyjemne wrażenie, które odczuwamy w jakiejś części ciała, np. po zranieniu się lub na skutek choroby.) (ISJP)

4 Jednostkę boleć odróżnia się od boleć, które reprezentuje predykaty II rzędu klasy verba sentiendi.

5 Tak jak poprzednio, ograniczam się tylko do struktur zupełnych, z pełną realizacją pozycji argumentowych. 
Por. też opracowanie hasła bułgarskiego боли ме - 1. изпитвам физическа болка (РБЕ)

(болка 1. Мъчително физическо усещане, причинено от различни видове дразнене или увреждане на живата тъкан.) (РБЕ)

Analogicznie definiowane są inne, bliskie znaczeniowo jednostki (różniące się wyrażanym rodzajem / stopniem doznania bólowego), jak np. kłuć, rwać, por.

kłuć 2. Jeśli kogoś kłuje w jakiejś części ciała , to odczuwa on w niej ostry, przenikający ból. (ISJP)

rwać 6. Jeśli rwie nas jakaś część ciała, to odczuwamy w niej ostry ból, zanikający i nasilający się na przemian. (ISJP)

Przytoczone parafrazy ukazują dominującą w nich (w sensie semantycznym i składniowym) pozycję dla predykatów odnoszących się do doznań / odczuć. Trudno też w związku z tym przyznawać frazom $N_{a}$ jedynie funkcję wskazywania całości w relacji całość : część. Można by ewentualnie upatrywać w tej pozycji proces kondensacji, który dotyczyłby na poziomie parafrazy pozycji argumentowej jednostki doznającej (Experiencer) oraz wyrażenia odnoszącego się do relacji całość : część, por. ??Piotr odczuwa nieprzyjemne wrażenie w jego nodze. Brak zdań typu ?? Boli mnie moja ręka. / ?? Annę boli jej ręka. w uzusie językowym można tłumaczyć obecnym w nich podwojeniem informacji ( $x$ - $a$ mogą boleć tylko $x$ - $a$ części ciała.). Nie są używane również zdania ${ }^{*}$ Moja ręka boli. Uwzględnienie tych cech skłania do zaliczenia predykatów typu boleć do dwumiejscowych.

5. Nie ulega wątpliwości, że do obiektów stanowiących części ciała jednostki ożywionej odnoszą się korelaty językowe o pewnych szczególnych cechach dystrybucyjnych, odróżniających je pod względem formalnej realizacji w strukturach zdaniowych od nazw odnoszących się do obiektów nieożywionych. Można tu przywołać różnice w cechach zdań w zależności od typu obiektu:

a) Chłopak kopnął w ścianę komórki. / Chłopak kopnął ścianę komórki. - ${ }^{*}$ Chłopak kopnął komórkę w ścianę.,

wobec

b) ?Chłopak kopnął w nogę kolegi. / Chłopak kopnął nogę kolegi. / Chłopak kopnął kolegę w nogę.

Przykłady predykatów typu boleć ukazują trudną problematyką ustalania ilości i rodzaju pozycji argumentowych w strukturach zdaniowych, a co za tym idzie, klasyfikacji predykatów. S. Karolak zawarł w (Karolak 1984, s. 54-56) istotne, eksplicytnie sformułowane warunki dotyczące procedury ustalania liczby pozycji argumentowych w strukturach predykatowo-argumentowych. Jak wiadomo, autor wskazuje, 
że podstawową procedurą jest dokonywanie tego na podstawie dekompozycji sensu danego wyrażenia predykatywnego na składniki elementarne (dalej nierozkładalne). Często konieczne jest także uwzględnienie kondensacji semantycznych doprowadzających do redukcji kilku powtarzających się pozycji argumentowych występujących w parafrazach analitycznych. Jednocześnie autor zwraca uwagę na to, że taka procedura może być obarczona pewnym subiektywizmem. Jako kryterium określające pozycję implikowaną (argumentową) autor ustala nieusuwalność (a więc obligatoryjność) semantyczną - usunięcie takiego składnika zmienia sens wyrażenia. W przypadku zdań $\mathrm{z}$ formami boleć $\mathrm{w}$ funkcji wyrażenia predykatywnego fraza odnosząca się do jednostki o cechach [+pers / +anim] $-\mathrm{N}_{\text {acc }}$ - jest obligatoryjna, por. niemożliwe poza kontekstem ${ }^{\star}$ Boli ręka. / ${ }^{\star}$ Ręka boli. Ta sama fraza w strukturze semantycznej odnosi się do jednostki, której częścią ciała jest ręka oraz tej, która cierpi. Przyjęcie tezy o spłynięciu obu pozycji w procesie redukcji zdublowanych treści występujących w parafrazie jest propozycją interpretacji struktury zdaniowej typu Boli mnie ręka.

6. Analiza klasy polskich czasowników typu pojaśnieć, posiwieć itp., otwierających zgodnie z koncepcją S. Karolaka pozycję argumentową o złożonej strukturze semantycznej, ukazała pewne nietrywialne problemy dotyczące ustalania cech badanych predykatów. Problemy klasyfikacyjne nasunęła także analiza struktur zdaniowych tworzonych przez czasowniki typu boleć, ujętych również w klasyfikacji S. Karolaka jako podklasa predykatów z argumentem osobowo-rzeczowym. Należą one do czasowników doznaniowych, w odróżnieniu od podklasy pociemnieć, wygładzić się, która komunikuje zmianę stanu obiektu.

6.1. Szczegółowa interpretacja semantyczna i syntaktyczna fraz typu włosy Joanny / косата на Иванка i ich wariantów w odmiankach struktur zdaniowych rodzi w niektórych wypadkach trudności w określeniu funkcji komponentu $\mathrm{N}_{\text {obiect }}$ Dotyczy to struktur typu Dziewczyna miała blada twarz. Interpretacja tego typu struktur jako fundowanych na predykacie jednomiejscowym mieć ${ }_{x}$ okazuje się trudna do udowodnienia (por. m. in. niedopuszczalne ${ }^{*}$ Blada twarz dziewczyny miała., analogicznie do akceptowanej Twarz dziewczyny pojaśniała.). W przeprowadzonej w artykule analizie predykat miećc uznaje się za dwuargumentowy, definicyjny dla wyrażania relacji całość : część.

6.2. Jak wskazano wyżej, w analizie podklasy czasowników typu boleć, kłuć, rwać również ujawnił się problem ustalania ilości argumentów charakteryzującej predykaty. Zdaniem autorki artykułu trudno ograniczyć funkcję argumentu osobowego w strukturach typu Adama boli gardło. jedynie do komponentu relacji całossć : część. Uwzględniając doznaniowy charakter predykatów typu pol. boleć, bułg. боли і odwołując się do typu parafrazy analitycznej, postuluje się uznanie takich czasowników za predykaty dwumiejscowe. 
6.3. Porównanie realizacji cech walencyjnych polskich czasowników typu pociemnieć, wygładzić się i ich bułgarskich odpowiedników typu потъмня, изгладя се ujawnia idiomatyczny charakter dopuszczalnych struktur zdaniowych i pozwala ukazać różnice konfrontatywne, które łatwo umykają uwadze. W inwentarzach dopuszczalnych struktur zdaniowych bułgarski charakteryzuje mniejsza ilość typów i preferowanie struktur, których nie charakteryzuje rozszczepienie syntaktyczne frazy typu лището на Иванка.

\section{Bibliografia}

Karolak, S. (1984). Składnia wyrażeń predykatywnych. W: Z. Topolińska. (red.), Składnia. Gramatyka wspótczesnego języka polskiego. Składnia - Morfologia - Fonologia (11-209). Warszawa: Państwowe Wydawnictwo Naukowe.

Korytkowska, M. (red.). (2019). A. Kiklewicz, M. Korytkowska, J. Mazurkiewicz-Sułkowska, A. Zatorska, Zintegrowany opis semantyczno-syntaktyczny czasowników bułgarskich, polskich i rosyjskich (verba cogitandi i verba sentiendi), cz. I-II (1 i 2), Warszawa: Instytut Slawistyki Polskiej Akademii Nauk \& Fundacja Slawistyczna. https://hdl.handle.net/20.500.12528/1087 [wydanie na platformie cyfrowej].

Kruk, D. (2019). Czasownik mieć - jednostka elementarna czy wykładnik operacji? Linguistica Copernicana 16 (214-228).

Polański, K. (red.). (1995). Encyklopedia językoznawstwa ogólnego, K. Polański WrocławWarszawa-Kraków: Zakład Narodowy imienia Ossolińskich. [hasła: zdanie podrzędne przydawkowe; transformacja zanurzająca, dativus, dativus possesivus]

Topolińska, Z. (2019). Raz jeszcze o pozycji datiwu (i genetiwu) w paradygmacie semantycznym kategorii przypadka, Rocznik Slawistyczny, LXVIII, 159-165.

Wierzbicka. A. (1986). The Meaning of a Case: A Study of Polish Dative. W: Case in Slavic (386-426), ed. R.D. Brecht, J.S. Levine, Colombus, Ohio: Slavica Publishers.

ABSTRAKT: Artykuł dotyczy interpretacji semantyczno-składniowej struktur zdaniowych, w których wyrażana jest relacja część : całość w odniesieniu do jednostki ożywionej (z cechą $\left[+\right.$ anim $_{/ \mathrm{i}}+$ hum $]$ oraz części jej ciała, np. Włosy Piotrusia ściemniały. (z wariantem Włosy Piotrusiowi ściemniały.). Autor odwołuje się do teoretycznych podstaw modelu składni zdania opartego na relacji predykatowo-argumentowej (w tym do fundamentalnej wersji S. Karolaka). Ukazane zostały dwa sposoby interpretacji omawianych struktur, w których predykaty konstytuujące struktury zdaniowe otwierają jedną pozycję dla argumentu. Przedyskutowana została struktura tego argumentu i ukazane odpowiedniki w języku bułgarskim. Odniesiono się także do opisu kolejnego typu czasowników (boleć), również otwierających w klasyfikacji S. Karolaka pozycję dla jednego, semantycznie złożonego argumentu. Zdaniem autora artykułu rozbudowanie struktury semantycznej tych czasowników o predykaty typu czuć / doznawać wpływa na ich klasyfikację dwuargumentową. 